\title{
Smallholder Farmers' Access to Inputs and Finance in Africa
}

\author{
Augustine Langyintuo
}

\begin{abstract}
Agriculture remains the mainstay of most economies in Africa, accounting for $37 \%$ of gross domestic product (GDP), nearly $60 \%$ of export earnings, and over $76 \%$ of employment. Over the decades, agricultural value added has averaged $17 \%$, growing at a rate of $1.4 \%$. This has been driven primarily by low use of modern technologies such as improved crop varieties, fertilisers and other complementary inputs, which in turn is an artefact of limited access to agricultural finance. The direct consequence of low agricultural productivity is the high rates of poverty and malnutrition on the continent. African governments are renewing efforts to promote agriculture, recognising that GDP growth originating in agriculture is about four times more effective in reducing poverty than GDP growth in other sectors, although how best to do this within very complex political economies remains a challenge. As an important first step towards reducing poverty and increasing wealth among smallholder farmers in Africa, this chapter explores the major challenges in farmers' access to productive farm inputs and finances and reviews alternative approaches that could be used to improve access by farmers to these resources.
\end{abstract}

\section{Introduction}

Agriculture remains the mainstay of the economies of many African countries. Nearly $60 \%$ of export earnings are from agriculture, and over $76 \%$ of the 987 million Africans living in rural areas are employed in agriculture (FAO 2010). Although agriculture's average contribution to GDP on the continent has been declining over time, it still remains high, averaging $37 \%$ with a range of $3-67 \%$. Whereas agricultural value added averages $17 \%$, value added per agricultural worker in 2003 (in 2000 USD) averaged USD 327, growing at a rate of $1.4 \%$, compared to USD 23081 at a rate of $4.4 \%$ in Organisation for Economic Cooperation and Development (OECD) countries during the same period (IAASTD 2009).

\footnotetext{
A. Langyintuo ( $\square)$

International Finance Corporation, World Bank Group, Delta Center, Menengai Road, PO

Box 30577, Upper Hill, Nairobi, Kenya

e-mail: alangyintuo@ifc.org

(C) The Author(s) 2020

S. Gomez y Paloma et al. (eds.), The Role of Smallholder Farms in Food

and Nutrition Security, https://doi.org/10.1007/978-3-030-42148-9_7
} 
In Africa, agricultural productivity growth over the decades has been disappointingly low. Observed increases in cereal production have been due, primarily, to increase in cultivated area (Fig. 1). By contrast, in Asia in the 1960s, production increases resulted from the rapid uptake of high-yielding wheat and rice varieties and the use of fertilisers and irrigation combined with subsidies, which drove down the cost of production and raised land and labour productivities (Hazell and Ramasamy 1991). The observed increases in production still fall short of population growth, compelling African governments to import cereals in the order of 50 million megatonnes, at an estimated cost of USD 30-50 billion a year. It is estimated that if continental food supplies do not increase, Africa will spend about USD 150 billion on food imports by 2030 (IFPRI 2012).

Numerous factors account for the low productivity of agriculture in Africa, not least the limited use of improved agricultural technologies, especially improved seeds, fertilisers and mechanisation services, which in turn is an artefact of the lack of access to agricultural finance. Additionally, the apparent lack of land tenure security is thought to be a hindrance to increased investment in land improvement technologies and to encourage the adoption of unsustainable agricultural practices, leading to poor family incomes and nutrition (UNECA 2005). The consequence of the low productivity in the predominantly agro-based economies on the continent is pervasive poverty. More than half of the extreme poor live in SSA, with around 413 million people living on less than USD 1.90 per day (Fig. 2) (World Bank 2013, 2018); a staggering 249 million are undernourished (FAO 2019).

Several experts have observed that the expansion of smallholder farming can lead to a faster rate of poverty alleviation, by raising the incomes of rural cultivators and reducing food expenditure, thus reducing income inequality (Magingxa and Kamara 2003; Diao and Hazell 2004; Resnick 2004; Barham and Chitemi 2008; World Bank

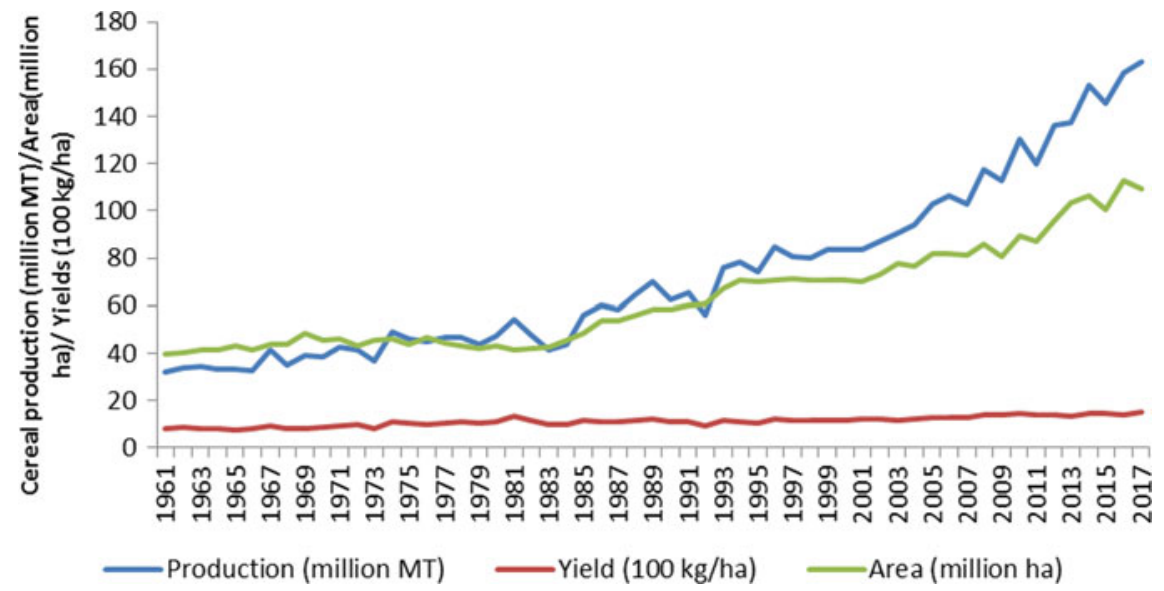

Fig. 1 Trends in cereal production, area planted and productivity in sub-Saharan Africa (SSA). Source FAO (2018) 


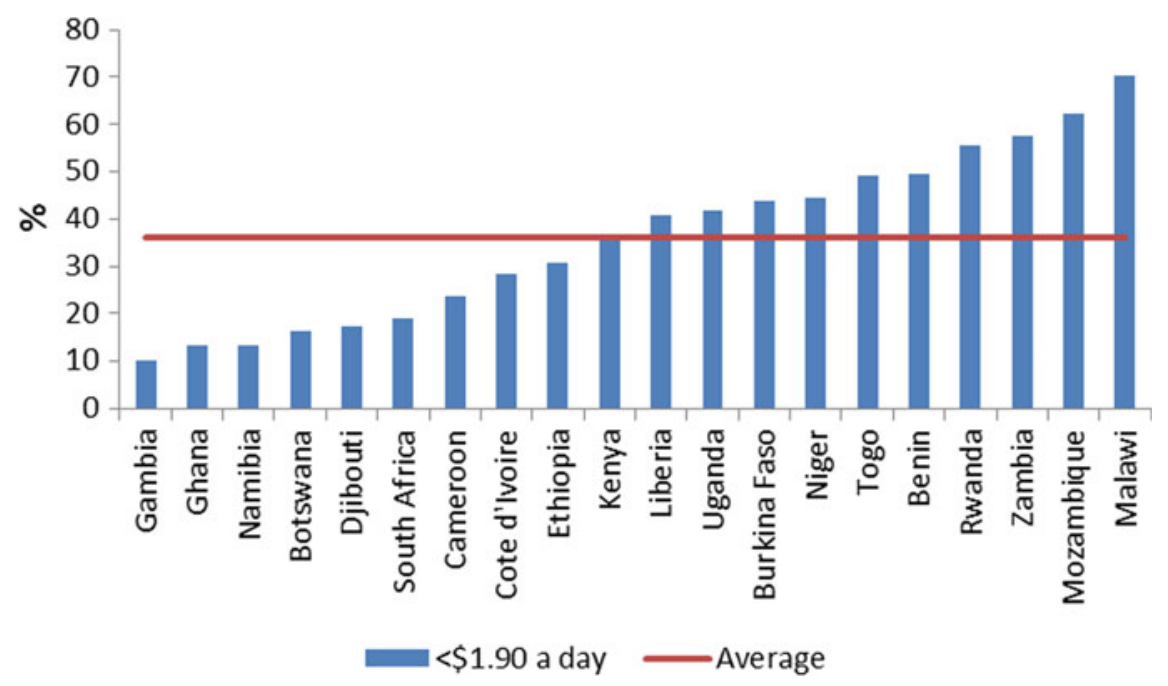

Fig. 2 Population living below the poverty line of USD 1.90/day (\%). Source World Bank (2018)

2008a). This is consistent with the 2008 World Development Report, which pointed out that GDP growth originating in agriculture is about four times more effective in reducing poverty than GDP growth in other sectors (World Bank 2008a). A 10\% increase in productivity can reduce poverty by $4 \%$ in the short run and $19 \%$ in the long run (FAO 2010).

In the light of this, most African governments embrace reduction of poverty and increase of wealth among smallholder farmers as important policy challenges. This is exemplified by the African Heads of State 2003 Maputo Comprehensive African Agricultural Development Programme (CAADP) declaration, which commits governments to spend at least $10 \%$ of their national budgets on agriculture to raise agricultural productivity to at least 6\% (NEPAD 2004); and the 2006 Abuja Declaration that 'given the strategic importance of fertiliser in achieving the African Green Revolution to end hunger, the African Union Member States resolve to increase the level of use of fertiliser from the current average of 8 kilograms per hectare to an average of at least $50 \mathrm{~kg}$ per hectare by $2015^{\prime}$.

Drawing on existing literature and secondary data, this chapter examines the major challenges to farmers' access to productive farm inputs and finances and explores alternative approaches that could potentially improve smallholder farmers' access to productive resources, as a contribution to government efforts to improve lots of rural households. The rest of the Chapter is organised as follows: Section 2 examines the challenges to smallholder farmers' access to production inputs, mainly land, seeds, fertiliser and finance. This is followed by a detailed discussion on strategies to improve smallholder farmers' access to inputs and finance in Sect. 3. Section 4 presents the concluding remarks on the chapter. 


\section{Challenges to Smallholder Farmers' Access to Production Inputs}

Farmers typically need various resources to organise agricultural production, but for the sake of this chapter we focus on purchased inputs (seeds and fertiliser) and access to finance. We acknowledge upfront that access to secure land is equally important, deserving a separate chapter, and it is therefore only briefly discussed here to contextualise the discussion.

\subsection{Limitations in Access to Secure Agricultural Land}

Africa accounts for over $60 \%$ of the available arable land on Earth. Nevertheless, smallholder farmers in Africa are unable to secure sufficient and suitable land to grow their crops and keep livestock. As shown in Fig. 3, land pressure is severe in Rwanda, Malawi, Kenya and Uganda, with an average holding of barely one hectare, compared to Burkina Faso, Mali, Niger and Ghana, where the average holding is more than three hectares. Not only is access a problem, the security of access is an even bigger problem facing farmers. This is partly because of the predominantly customary land tenure system observed in many countries including Mali, Zambia, Malawi, Ghana, Burkina Faso and Niger and in large parts of Sierra Leone, Liberia, Nigeria, Tanzania and Mozambique. Under such tenure arrangements, land tends to be held collectively by lineages or families without providing any form of security to users, especially women and young people (Namubiru-Mwaura et al. 2012). In most parts of Africa,

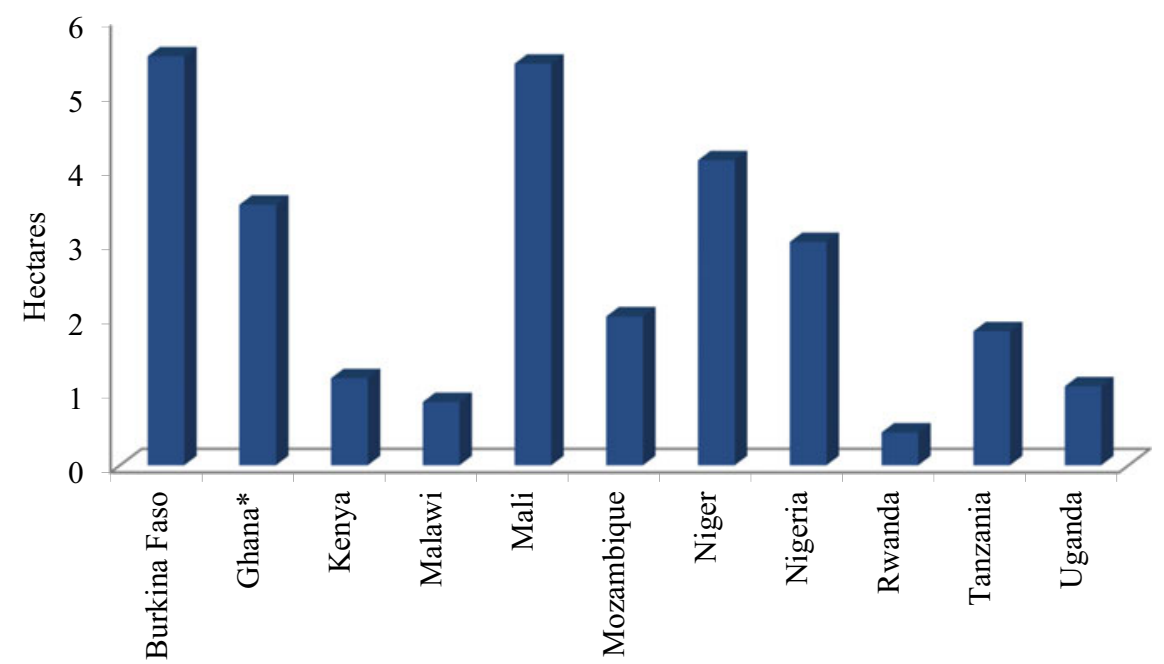

Fig. 3 Average area of agricultural land per household (2009-2010). Source AGRA (2014) 
women's rights to land are limited to 1-2\% of land and dependent on their marital statuses, although evidence suggests they contribute more than $70 \%$ of agricultural labour (Bennett 2010). The problem of land tenure insecurity is exacerbated by state interference, through acquisitions and forceful seizure of farmlands in the name of investment.

Tenure security affects agricultural productivity through the choice of crop to grow, limited investment in land and adoption of unsustainable agricultural practices (UNECA 2005). Although privatisation of land would seem to be effective in reducing insecurity, evidence seems to suggest that although short-term land rentals improve land productivity (Kebede 2002; Holden et al. 2008), they provide no incentives for either the landlord or the tenant to make long-term improvements (Place 2009), thereby compromising on sustainable production.

Land productivity is largely influenced by access to reliable water sources, especially under predominantly rainfed conditions often characterised by significant climatic variability. About $60 \%$ of SSA is exposed to drought, and $30 \%$ extremely (Hodson et al. 2009), yet irrigation facilities are limited (Fig. 4). Most of the existing irrigation facilities are ineffectively and inefficiently utilised. This is because constructions are often fraught with problems, such as generally insufficient farmer involvement in design; development often far removed from existing farming systems; inadequate land tenure system development for irrigation; capital-intensive investment requiring high input levels; and chronic institutional weaknesses.

The Intergovernmental Panel on Climate Change 2007 Report predicts that up to 250 million people in Africa will experience problems in accessing sufficient water by 2020 because of climate change, potentially leading to halving of agricultural

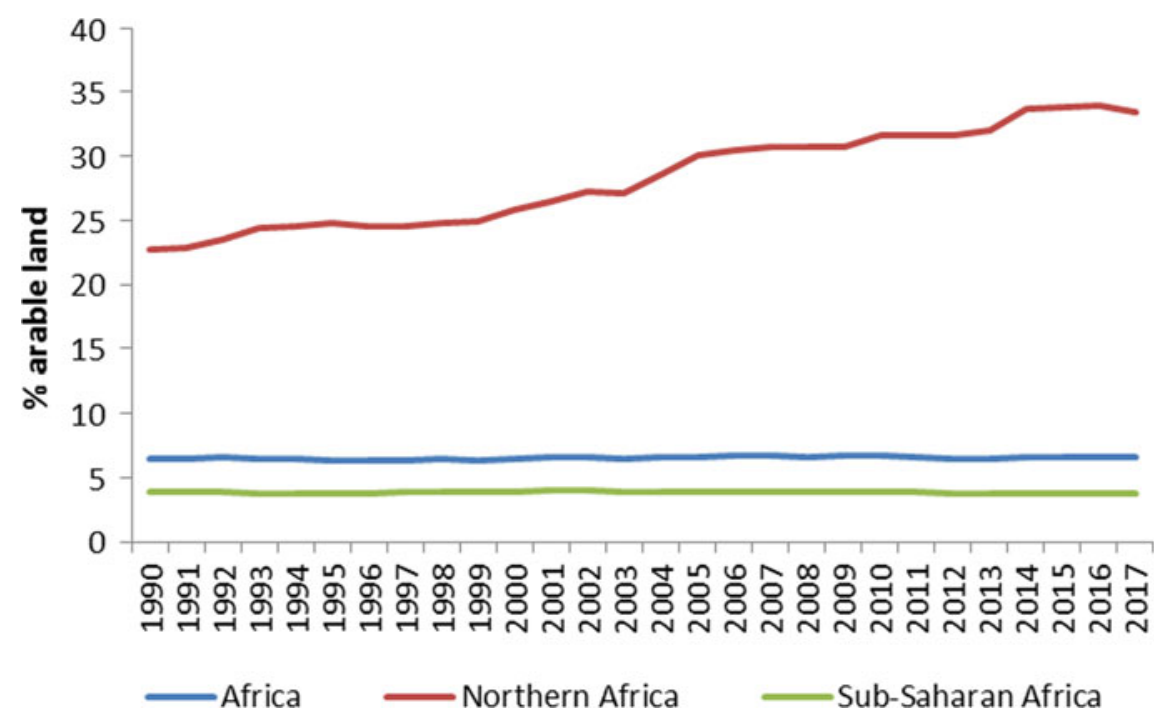

Fig. 4 Percentage of arable land equipped with irrigation. Source FAO (2019) 
production (IFPRI 2012). The report also predicts that, without adaptation, the impact of climate change on agriculture and food security will be high, with the number of malnourished children possibly increasing by an extra 10 million to a total of 52 million by 2050 .

\subsection{Policies and Institutional Factors Hindering Farmers' Access to Improved Seed}

Seed is an essential, strategic and relatively inexpensive input to agriculture, with a high rate of return on investment that often sets the upper limit for crop production. Improved seeds typically yield 4-6 mt/ha, compared to traditional unimproved ones that yield less than $1 \mathrm{mt} / \mathrm{ha}$. Yet the uptake of the former is limited in Africa. Langyintuo et al. (2010) suggest that the adoption rates for improved maize ${ }^{1}$ seed average $28 \%$ of the cultivated area of approximately 17 million ha (Table 1). This low adoption rate is blamed on a combination of policy and technical problems that hinder the supply of and demand for improved seeds. On the demand side, risk aversion among farmers, lack of knowledge of the availability of ecologically adapted varieties, relatively high seed price and lack of cash resources are the main determinants of adoption. The high-risk aversion observed among smallholder farmers is due

Table 1 Adoption rate of improved maize varieties in selected countries in Africa

\begin{tabular}{l|l|l|l}
\hline Country & $\begin{array}{l}\text { Area (million } \\
\text { ha) }\end{array}$ & $\begin{array}{l}\text { Seed demand } \\
(1000 \mathrm{t})\end{array}$ & $\begin{array}{l}\text { Adoption } \\
\text { rate }(\% \text { of } \\
\text { area) }\end{array}$ \\
\hline Ethiopia & 1.7 & 42 & 19 \\
\hline Kenya & 1.6 & 39 & 72 \\
\hline Tanzania & 2.6 & 64 & 18 \\
\hline Uganda & 0.7 & 17 & 35 \\
\hline Angola & 0.8 & 19 & 5 \\
\hline Malawi & 1.4 & 35 & 22 \\
\hline Mozambique & 1.2 & 30 & 11 \\
\hline Zambia & 0.6 & 14 & 73 \\
\hline Zimbabwe & 1.4 & 34 & 80 \\
\hline Benin & 0.7 & 16 & Na \\
\hline Ghana & 0.7 & 19 & 1 \\
\hline Mali & 0.3 & 8 & 0.3 \\
\hline Nigeria & 3.6 & 89 & 5 \\
\hline Total/average & 17.3 & 427 & 28 \\
\hline
\end{tabular}

Source Langyintuo et al. (2010)

\footnotetext{
${ }^{1}$ Maize is one of the most important food crops grown in Africa.
} 
to the absence of physical assets, which diminishes their risk-bearing abilities, and hence, their reluctance to invest in untried technologies, including improved seed.

The lack of knowledge of adaptable varieties is primarily due to weak extension service delivery, relative to the numerous unfamiliar varieties released onto the market without adequate farmer education on the types and economic benefits of improved varieties, to improve their adoption decisions. Unfortunately, extension coverage is weak and sometimes skewed towards the relatively richer farmers (Langyintuo and Setimela 2007). Farmer confidence in the improved seed is sometimes further eroded by the proliferation of fake seeds on the market.

Some unscrupulous traders engage in unethical advertising practices, or simply painting grains in colours similar to known and trusted genuine varieties, to undercut prices. This not only cheats farmers out of their meagre cash resources, but permanently damages the loyalty built over time.

The relatively high seed prices are the combined effects of market policy failures and supply-side imperfections (discussed below). Whereas market imperfections sometimes cause misalignment of seed and grain prices, policy failures often lead to high production and marketing costs, poor seed quality assurance and uncompetitive seed markets leading to inferior pricing mechanisms ultimately affecting farmers negatively. For example, policymakers often attempt to improve consumer welfare by imposing price ceilings on outputs, as part of their market reforms strategy, without any attempt to make similar adjustments to seed prices. The end result is that farmers, who are less organised, are forced to buy seed at relatively high prices, thereby subsidising urban consumers to prevent urban unrest at the expense of their own welfare. Although free seed handouts by governments and non-governmental organisations are designed to address the liquidity constraints of farmers, they are known to have negative impacts on rural seed market development, as beneficiaries tend to be unwilling participants in the commercial seed market.

Although many countries have made significant progress in liberalising and restructuring their seed sectors in the past two decades (Hassan et al. 2001), some still operate dated seed policies or none at all, partly contributing to the incidence of fake seeds (Langyintuo 2004). Where policies exist, they almost exclusively concentrate on the formal seed sector and fail to support the diversity of initiatives that farmers employ for their seed security (Louwaars and Engels 2008). In most cases, the emphasis is always on hybrids to the neglect of open-pollinated varieties, as observed in India by Spielman et al. (2009).

Even where there are updated policies, their implementation may sometimes pose a significant challenge to seed sector development. For instance, most national governments in Africa insist on the registration of all newly developed varieties, to ensure the genetic identity of the variety and discourage the release of germplasm that is inappropriate, unproductive or unsafe. However, the registration processes have been observed in many countries to be very lengthy (up to three or more years) and expensive. Depending on the country, a breeder may pay between USD 1000 and USD 2500 per entry per year for both national performance trials (NPTs) and the distinctness, uniformity and stability (DUS) test, which are necessary components of the registration process (Langyintuo et al. 2010; Mwala and Gisselquist 2012). 
Not only are these costs ultimately passed on to farmers, but the process lengthens the time it takes farmers to access newly developed varieties.

Regional spillover of genetic improvement, through harmonisation of regional seed laws, can significantly reduce the costs of seed development and shorten the time it takes for farmers to benefit from improved genetics. Unfortunately, this has become problematic because the legislative frameworks of countries within regional economic communities vary widely in facilitating harmonisation. For example, plant variety protection is not enforced in countries such as Angola, Malawi, Uganda and all West African countries excluding Ghana. Ethiopia and Uganda are yet to update their Seeds Acts, while International Seed Testing Association (ISTA ${ }^{2}$ ) and OECD accreditation required for official seed shipment across borders are available in only Ghana, Kenya, Malawi, South Africa, Zambia and Zimbabwe. Differences in certification systems, standards and procedures have led to diminished trust among seed certification authorities in the different countries.

It is important to comment on the use of biotechnology in crop genetic improvement. For many years, biotechnology has been providing value-added foods and medicines for mankind. Recent advances in genomics, including the ability to insert genes across species, have distinguished 'modern biotechnology' from traditional methods. Resulting transgenic or genetically modified (GM) crops, forestry products, livestock and fish have potentially favourable qualities such as pest and disease resistance, however, with possible risks to biodiversity and human health (Paarlberg 2014). With the exception of four African countries (Table 2), the use of GM varieties remains controversial, largely driven by negative perceptions originating from Western consumers and exported to Africa (De Groote et al. 2014; Clive 2012; Paarlberg 2000, 2002, 2008). It is important to point out that GM crops have been subject to more testing worldwide than any other new crops and have been declared as safe as conventionally bred crops by scientific and food safety authorities worldwide (Paarlberg 2014). As noted by Paarlberg (2014), a recent EU report concludes that more

Table 2 Area planted to GM crops in Africa in 2012 (ha)

\begin{tabular}{l|c|c|c|c}
\hline \multirow{2}{*}{ Country } & \multicolumn{2}{l}{ Crop planted } & \multirow{2}{*}{ Total } \\
\cline { 2 - 5 } & Cotton & Soybean & Maize & \\
\hline Burkina Faso & 300,000 & 0 & 1000 & 300,000 \\
\hline Egypt & 0 & 0 & 1873,000 & 2300,000 \\
\hline South Africa & 15,000 & 362,000 & 0 & 200,000 \\
\hline Sudan & 200,000 & 0 & 1874,000 & 2801,000 \\
\hline Total & 515,000 & 382,000 & 000 \\
\hline
\end{tabular}

Source Compiled from Clive (2012)

\footnotetext{
${ }^{2}$ A country without an ISTA-accredited laboratory, such as Angola, Ethiopia, Mozambique, Tanzania or Uganda, cannot sell seed across borders, since any cross-border traded seed lots must bear ISTA Seed Lot and Sample Certificates, to certify that the seed has met the requirements of the ISTA rules.
} 
than 130 EU research projects, covering a period of more than 25 years of research and involving more than 500 independent research groups, concur that consuming foods containing ingredients derived from GM crops is no riskier than consuming the same foods containing ingredients from conventional crops. Such well-known organisations as the World Health Organization, the US National Academy of Sciences and the European Food Safety Authority (EFSA) have come to the same conclusion (Paarlberg 2014).

\subsection{Constraints to Smallholder Farmers' Access to Fertiliser in Africa}

Organic and inorganic (or mineral) fertilisers are strategic inputs to crop production, especially where the existing soils are exhausted from continuous cropping without adequate soil amelioration. Evidence shows that about $25 \%$ of crop production is lost each year without application of nitrogen fertiliser; by the 10th year, $60 \%$ is lost (Donovan and Casey 1998). Nonetheless, the average consumption of inorganic fertilisers is very low, at around $16 \mathrm{~kg} / \mathrm{ha}$ of nutrients-ranging from less than $1 \mathrm{~kg} / \mathrm{ha}$ in Niger and Gambia to about $89 \mathrm{~kg} / \mathrm{ha}$ in South Africa (Fig. 5). This is compared with $331 \mathrm{~kg} / \mathrm{ha}$ in East Asia and Pacific and $160 \mathrm{~kg} / \mathrm{ha}$ in South Asia and over $180 \mathrm{~kg} / \mathrm{ha}$ in the upper middle income world (World Bank 2019). Within SSA, Zambia, South Africa and Côte d'Ivoire have achieved the target in the Abuja Declaration of $50 \mathrm{~kg} / \mathrm{ha}$. Whereas high levels of fertiliser use create environmental problems in developed countries and in a few countries in Africa such as Egypt and

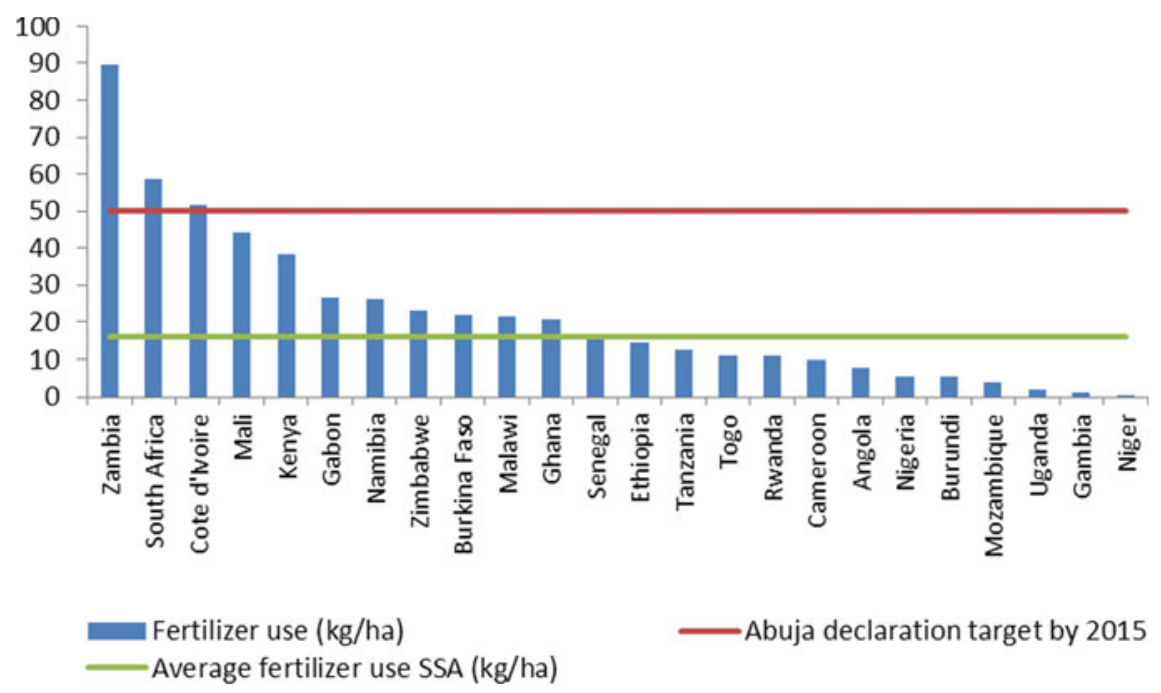

Fig. 5 Intensity of fertiliser use in selected countries in Africa. Source World Bank (2019) 
Morocco, in most parts of Africa, the limited use of the input creates environmental degradation leading to an estimated loss of 4-12\% of GDP, through soil mining and clearing of forest land to expand farms in an attempt to increase production (Olson and Berry 2003).

It is believed that demand and supply-side policy failures are to blame for the limited use of fertilisers in Africa. On the demand side, the risk of fertiliser use and the poor nitrogen to maize price ratio that has been trending downward by $0.9 \%$ are a disincentive to fertiliser use (Gregory and Bumb 2006; Heisey and Norton 2007; Morris et al. 2011). Because most of the crops grown by farmers are staples and non-tradable while fertilisers are imported, currency devaluation often increases the price of fertiliser several times above output prices.

In addition, fertiliser prices are uncompetitive because of the slow emergence of the private sector and consequent lack of a vibrant market, which in turn is an artefact of unfavourable private-sector policies: poorly defined rules of the game, weak regulatory enforcement, proliferation of taxes and fees, cumbersome bureaucratic importation procedures, general lack of security and widespread incidence of corruption (World Bank 2006). Prices are further increased by poor road infrastructure and the cost of finance. Added to the many official and unofficial tolls and taxes, security check points along the roads slow the delivery of services and impose transaction costs.

Unfortunately, the high cost of importation and distribution of fertiliser is likely to remain for a long time to come. At the present level of African fertiliser markets development it is cost-effective to import until markets expand to support large-scale local production (World Bank 2006). Presently, over 90\% of the fertiliser used in Africa is imported at very high sourcing costs, which ultimately reduce the profitability of distributing fertiliser and discourage increased supply. The scope for negotiating bulk purchases and arranging bulk shipments in order to save on freight charges is limited by the lack of port facilities capable of handling large volumes. ${ }^{3}$

\subsection{Access to Agricultural Finance for Smallholder Farmers}

Agriculture is the predominant activity in African economies, yet less than $4 \%$ of total commercial bank lending goes into the agricultural sector (Fig. 6). Financial institutions often cite lack of usable collateral, high transaction costs due to remoteness of clients, dispersed demand for financial services, the lag between investment needs and expected revenues, lack of irrigation, pests and diseases, small size of farms and of individual transactions, underdeveloped communication and transportation infrastructure and high covariate risks due to variable rainfall and price risks (Adesina

\footnotetext{
${ }^{3}$ Most of the fertiliser imported into Africa is shipped via 10,000 tonne vessels because of limited capacities at the ports, especially those outside of South Africa. This limits the size of bulk orders and entails a shipping cost premium of $10-15 \%$ over medium-sized vessels (Morris et al. 2011). All these factors negatively affect farm gate prices, thereby constraining the use of fertiliser by smallholder farmers.
} 


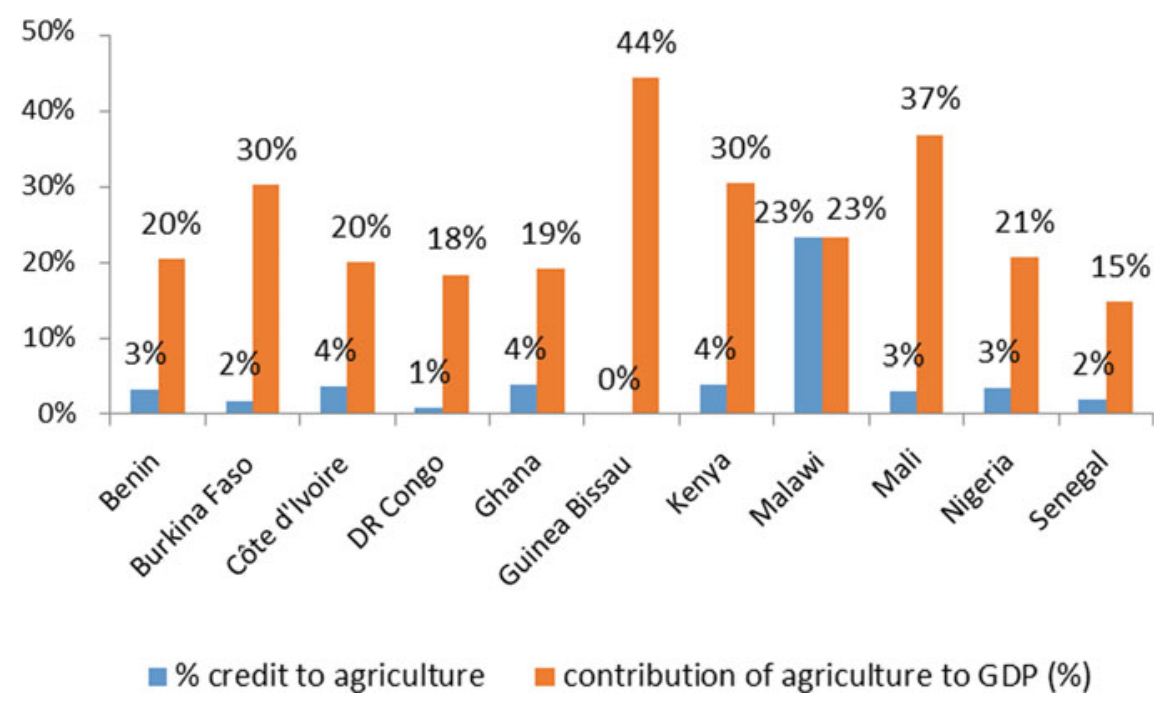

Fig. 6 Agricultural lending as a share of agricultural GDP in selected African countries. Source FAO (2018)

et al. 2012) as reasons why they do not lend to smallholder farmers. Other challenges include poorly developed agri-food value chains, which significantly increase risks and exposure for the bank, and general lack of understanding among financial institutions of the agricultural sector and the opportunities.

In principle, the unsatisfied demand by smallholder farmers and SMEs for financial services can be met by microfinance institutions (MFIs). These institutions have emerged to provide credit facilities and deposits but have not succeeded in expanding financing for agriculture, due to a number of reasons including limited capital bases, high interest rate, small size of disbursement insufficient for investment and being located in urban centres when the bulk of farmers are in rural areas. Moreover, the repayment schedules for microfinance loans often do not synchronise with the seasonality of agriculture and the timing of farmers' cash flows.

Furthermore, Poulton et al. (2006) noted that some of the challenges faced by MFIs included very small outreach compared to demand, inadequate capacity to properly conduct credit analysis and loan appraisals, inadequate risk management and control systems, small shares of total deposits and loans compared to commercial banks, non-performing collateral laws limiting the effectiveness of the MFIs and inadequate capitalisation limiting levels when assessing the potential of default by a prospective borrower. 


\section{Strategies to Improve Smallholder Farmers' Access to Inputs and Finance}

\subsection{Improving Security of Land Access}

In recent times, there has been some progress in the development of land policy frameworks in Africa, but a recent report (FAO 2010) showed that many of them are weak in addressing ethnic and gender issues, land information systems and monitoring mechanisms. This is possibly because, under customary systems, the land is usually accessed through complex social relations governed by local institutions, and hence, national land policies and laws often have little relevance. Therefore, any policy reform must be tailored to the physical, social and economic contexts, as well as taking into consideration economic factors, equity issues and less tangible concerns such as the social or religious beliefs that people attach to land. The framework should also consider the capacity of the country to implement such policies.

\subsection{Facilitating Access to Improved Seeds}

It is apparent from the analysis that adoption rates are low and farmers' propensity to buy seed can be enhanced in a number of ways. Firstly, farmers need to know about the existence, characteristics and economic value of a given variety, through the dissemination of timely extension messages. This seems to be lacking due to weak extension systems. To address this problem, some seed companies invest in extension message delivery, for instance by simply printing symbols on the seed packs that depict the maturity group of the variety. For example, SeedCo Limited uses the image of an elephant for a long maturing variety and a zebra for an early maturing variety.

Secondly, farmers need credit themselves to be able to purchase the seed. Partly due to the non-competitive nature of the seed industry, seeds are generally priced above the means of farmers and their participation in the seed market would require support through targeted subsidies or subsidised farm credit.

Thirdly, farmers deserve better returns on their investment in seeds to encourage them to continue to invest. Efforts to make output value chains profitable are critical in enhancing seed demand.

Finally, governments need to pursue some key reforms to improve the supply side. These include updating seed legislature to be consistent with the development of the sector and to be private sector-friendly to encourage private investment. The public sector should demonstrate a willingness to domesticate harmonised regional seed laws, regulations and standards to promote regional seed trade. Given the widespread faking of seeds in the region, legislation should provide for stiffer punishment for those convicted of the offence, as a deterrent to others. 
In terms of biosafety, countries need a functional legislative framework encompassing the relevant policies, laws, regulations and requisite administrative structures and processes to safely harness GM technology. It is acknowledged that most African countries are at various stages of creating enabling environments for GM crop commercialisation. Five countries (Cameroon, Kenya, Malawi, Nigeria and Uganda) are currently conducting field trials of biotech crops, the final step before full approval for commercialisation.

\subsection{Promoting Fertiliser Access for Farmers}

To encourage farmers to use fertilisers, the practice of using blanket fertiliser recommendations, which are sometimes sub-optimal in specific situations, should be discouraged in favour of ecology/crop-specific rates. There should be an emphasis on the use of micronutrients and on demonstrating the profitability of fertiliser use. Strategies that enhance fertiliser use, such as microdosing and organic/inorganic fertiliser combinations, should also be considered. While appreciating the economic burden on governments and development partners, it is important to provide smart subsidies to farmers to promote fertiliser demand (Jayne and Jones 1997; Kelly et al. 2003).

On the supply side, government regulations are required to ensure competitive supply chains, which at present are generally weak in many countries. Efforts should be made to prevent importers and wholesalers from collusive practices, including price fixing and market segmentation.

Public policies should address fertiliser sourcing ${ }^{4}$ costs and distribution costs, the availability and cost of business finance and risk management instruments. Adequacy of supply chain coordination mechanisms could improve the fertiliser value chain. Other areas of policy intervention include access to foreign exchange and credit, and strengthening port infrastructure. Expanding capacity in the main ports of entry to allow larger vessels to discharge can help reduce the landed cost of fertiliser.

\subsection{Facilitating Agricultural Finance for Smallholder Farmers}

The financing gap in agriculture created by the commercial banks may be closed by exploring various options, including credit guarantees, interlocked markets for finance and warehouse receipts systems.

\footnotetext{
${ }^{4}$ Sourcing costs could be reduced through pooling import orders.
} 


\subsubsection{Credit Guarantee Schemes}

To address the perception of high risk and lack of collateral limiting commercial banks' lending to farmers, various development practitioners have rolled out innovative financing approaches, including credit guarantee schemes over the past few years. Credit guarantees have been used to cover part of the default risk, ensuring secure repayment of all or part of the loan in case of default (Levitsky 1997). Besides covering the default risk, credit guarantees are useful in addressing the issue of lack of collateral and poor credit history faced by farmers, and hence improve loan terms. Additionally, allowing loans to be made to borrowers who would otherwise have been excluded from the lending market enables farmers and SMEs to establish a repayment reputation in future (De Gobbi 2002) and benefit from lower transaction costs and helps to raise productivity (Ruiz Navajas 2001; Green 2003).

The use of credit guarantee schemes must be guided by best practice (World Bank 2008), as discussed here. Firstly, whether the scheme should focus on individual or portfolio loans is important. In an individual loan arrangement, the application is approved by the guarantor and the application is assessed on a case by case basis, thereby establishing a direct link between the borrower and the lender. An estimated $72 \%$ of credit guarantee schemes use this selective or individual loan approach (World Bank 2008b). While allowing for more careful risk management and likely reducing the probability of moral hazard, this approach introduces a high cost of loan management.

Secondly, the fees charged for the use of credit guarantees have a direct impact on the incentives for lenders and borrowers in participating in the scheme, as well as on the financial sustainability of the fund. Although it is not realistic to expect credit guarantees to cover full costs through fees, the fees must be high enough to cover administrative costs, but low enough to ensure adequate lender and borrower participation.

Thirdly, the default rate is an important indication of the sustainability of a guarantee scheme. A sustainable scheme should aim to have a default rate of $2-3 \%$, thanks to a critical assessment of the application and effective monitoring. Newly established schemes in developing countries might consider a higher default rate (i.e. over 5\%) in their early years of operation, but should aim at lower rates in the shortest possible time. In general, guarantee payouts should only be used if all efforts by the guarantors to reschedule payments have failed.

Fourthly, the risk-sharing arrangement between guarantor, lender and borrower defines the efficiency and effectiveness of the guarantee scheme. An improperly designed guarantee scheme can increase moral hazard among borrowers by reducing the default risk they would otherwise face, while a properly designed guarantee scheme can limit moral hazard. The guarantor should accept enough risk to be able to persuade banks to participate in the scheme, while reducing the scope for moral hazard or adverse selection. The level of risk sharing depends on which part of the agricultural value chain the scheme intends to focus on. For lending towards the upper part of the agricultural value chain - agro-processors, agro-dealers, fertiliser and seed companies, etc.- direct risk sharing at 50:50 would be sufficient, as the 
risk of lending is lower. For lending to the lower part of the agricultural value chain, especially to poor smallholder farmers, higher levels of risk-sharing arrangements such as first loss arrangements will be required. In general, a risk-sharing rate below $50 \%$ reduces the potential for moral hazard but tends to reduce the incentives for banks to participate in the guarantee scheme, because of high loan administration costs (World Bank 2008b).

Lastly, guarantee schemes should consider using risk management mechanisms such as reinsurance, loan sales or portfolio securitisation, in order to reduce the exposure to default and diversify risk. Globally, about $76 \%$ of credit guarantee schemes use risk management tools, $20 \%$ loan insurance, $10 \%$ securitised loans portfolio and $5 \%$ risk management strategies (World Bank 2008b). It should, however, be noted that these mechanisms require relatively well-developed local capital and financial markets.

\subsubsection{Interlocked Markets for Credit and Value Chain Financing}

One way of overcoming missing markets in the supply of credit to farmers for purchasing improved seeds and fertilisers is to use value chain or interlocked markets for inputs, outputs and credit (Poulton et al. 1998). Traditionally done through government-controlled parastatal agencies (Poulton et al. 1998), this type of value chain financing - including contract farming, vertically integrated operations or outgrower schemes-has often been viewed as the major source of credit for farmers (IFAD 2003). This has often been led by the private sector and dominated by agroprocessors, agribusinesses and traders, and food-processing companies-either local or international-operating under international markets have emerged (Swinnen and Maertens 2010). These value chain financing arrangements are becoming increasingly important for farmers, especially in export-oriented value chains such as horticulture, as a source of finance for inputs and markets for the outputs. For example, farmers growing cash crops such as cotton sometimes receive fertilisers for these crops but also use the inputs on their food crops, inevitably increasing and sustaining cash and food crop production (Dione 1991).

There are many advantages to interlocked credit market arrangements, not least the low risk of default because the cost of inputs is deducted before the farmers receive payments for the produce delivered. It also offers assured markets, guaranteed prices, reduced marketing risks and sharing of lending risks with positive spillover effects on other crops (Swinnen and Maertens 2010). Monitoring and supervision costs are also reduced since the input loan is delivered in kind to farmers to be applied on their crops, except when farmers engage in side selling of the produce. This practice is particularly difficult to curb where there are no appropriate legal frameworks to enforce contracts. 


\subsubsection{Warehouse Receipts System (WRS)}

WRS is becoming an important instrument for accessing financing from commercial banks. As noted earlier, one of the reasons why banks are reluctant to lend to agriculture is the lack of collateral for loans. The absence of land titles and other encumbered fixed assets that could be used as collateral, as well as the lack of indemnity for product quality deterioration and storage losses, diminishes banks' willingness to lend to the agricultural sector. A WRS can potentially be used to unlock the collateral value of inventories that farmers, traders and processors manage through warehouse receipt financing, helping to relieve some of the existing constraints to accessing credit.

A producer, farmer group, trader, exporter, processor or indeed any individual or body corporate may deposit grains or other commodities into a registered warehouse. The warehouse operator issues the depositor with a warehouse receipt (WR), ${ }^{5}$ which stipulates the quality, quantity and type of commodity, the date deposited and the date up to which storage costs have been paid (Swinnen and Maertens 2010). The warehouse operator holds the stored commodity by way of safe custody, implying he is legally liable to make good at any value lost through theft or damage by fire and other catastrophes, but has no legal or beneficial interest in it.

There are many benefits to the WRS, including easing rural finance, reducing storage losses, improving grades and standards, facilitating trade, enhancing market efficiency, mitigating price risks and enabling cost-effective management of public food reserves (Coulter and Onumah 2002). Focusing on the easing of rural finance, the depositor can take the warehouse receipt to a bank or other financial institution as collateral for a short-term loan, usually up to $60-70 \%$ of the value of the crop. Availability risk associated with movable collateral is reduced by the warehouse operator's guarantee of delivery from a stated location, and foreclosure can be simple and low cost without any resort to the courts, depending on the legal regime (Coulter and Onumah 2002). The risk of loss of value of the collateral can be minimised by monitoring movements in its market value and using margining and price risk management instruments. Lenders no longer need to monitor a large number of small borrowers, just a few warehouse operators, to assure loan performance. This ultimately reduces monitoring costs and encourages commercial lending to the rural sector, helping to capitalise the rural trade.

\section{Concluding Remarks}

Agriculture is the mainstay of the economies of African countries but productivity growth has been disappointingly low, perpetuating hunger and poverty. The main

\footnotetext{
${ }^{5}$ The receipts may be transferable, allowing transfer to a new holder-a lender (where the stored commodity is pledged as security for a loan) or a trade counterparty - which entitles the holder to take delivery of the commodity upon presentation of the WR at the warehouse.
} 
reasons for the poor performance of the agricultural sector have been a combination of low use of improved agricultural technologies (mainly seeds and fertiliser) and dysfunctional production and marketing policies. To reverse the trend, priority support to the sector should focus on the implementation and enforcement of predictable private-sector-friendly laws and regulations. Opening up market opportunities for inputs and outputs, through the enforcement of regional harmonisation, would increase the spillover impacts of technologies, thereby lowering the cost of inputs. Additionally, priority areas to promote agricultural transformation in Africa should include the development of financial policies that are coherent and privatesector-friendly and implementing risk-sharing instruments to leverage commercial bank credit into agriculture to capitalise the sector.

\section{References}

Adesina, A. A., Langyintuo, A., Bugo, N., Makinde, K., Bigirwa, G., \& Wakiumu, J. (2012). Improving farmers' access to agricultural inputs and finance: Approaches and lessons from subSaharan Africa. In Hazell et al. (Ed.), New directions for smallholder agriculture. Oxford: Oxford University Press.

AGRA (Alliance for a Green Revolution in Africa). (2014). African agriculture status report. AGRA, Nairobi, Kenya.

Barham, J., \& Chitemi, C. (2008). Collective action initiatives to improve marketing performance lessons for farms groups in Tanzania: Collective action for property rights (CAPRI). Working paper No. 74.

Bennett, P. (2010). Women's rights and access to land in Africa. New Agriculturist.

Clive, J. (2012). Global status of commercialized biotech/GM Crops: 2012 (ISAAA Brief No. 44). ISAAA: Ithaca, NY.

Coulter, J., \& Onumah, G. (2002). The role of warehouse receipt systems in enhanced commodity marketing and rural livelihoods in Africa. Food Policy, 27, 319-337.

De Gobbi, M. (2002). Making social capital work: Mutual guarantee associations for artisans, social finance programme, employment sector. International Labour Organisation, September.

De Groote, H., Kimenju, S. C., Keter, F., Ngigi, O., \& Gitonga, Z. (2014). But what do rural consumers in Africa think about GM food? Paper Prepared for presentation at the 18th ICABR Conference, Nairobi, June 2014.

Diao, X., \& Hazell, P. (2004). Exploring market opportunities for African smallholders. In 2020 Conference Brief No. 6. Washington D.C., USA: International Food and Policy Institute.

Dione, J. (1991). Food security and policy reform in Mali and the Sahel. In P. Dasgupta (Ed.) Issues in Contemporary Economics: Proceedings of the Ninth World Congress of the International Economic Association (Vol. 3). London: Macmillan).

Donovan, G., \& Casey, F. (1998). Soil fertility management in sub-Saharan Africa (60 p) (World Bank technical paper No. 408). Washington DC, USA: World Bank.

FAO (Food and Agriculture Organization of the United Nations). (2010). Africa's changing landscape: Securing land access for the rural poor. Rome, Italy. Available at http://www.fao.org/ docrep/012/al209e/al209e00.pdf.

FAO (Food and Agriculture Organization of the United Nations). (2018). Credit to agriculture data. Available at: http://www.fao.org/economic/ess/investment/credit/en/.

FAO. (2019). The state of food security and nutrition in the world. Safeguarding against economic slowdowns and downturns. Rome, Italy: Rome. Food and Agriculture Organization of the United Nations. Available at http://www.fao.org/state-of-food-security-nutrition/en/. 
Green, A. (2003). Credit guarantee schemes for small enterprises: An effective instrument to promote private sector-led growth? The United Nations Industrial Development Organization (UNIDO). Working Paper No. 10, August.

Gregory, D. I., \& Bumb, B. L. (2006). Factors affecting supply of sub-Saharan fertilizer in Africa (Agriculture and rural development discussion paper 24). Washington, DC: World Bank.

Hassan, R. M., Mekuria, M., \& Mwangi, W. M. (2001). Maize breeding research in eastern and southern Africa: Current status and impacts of past investments by the public and private sectors, 1966-1997. Mexico, D. F. (Mexico): CIMMYT.

Hazell, P. B. R., \& Ramasamy, C. (1991). The green revolution reconsidered: The impact of high yield rice varieties in South India (Food Policy Statement Number 14. International Food Policy Research Institute) Washington, DC. USA.

Heisey, P. W., \& Norton, G. (2007). Fertilizer and other farm chemicals. In R. E. Evenson, P. Pingali, \& T. P. Schultz (Eds.), Handbook of agricultural economics. Agricultural development: Farmers, farm production, and farm markets (Vol. 1,3A). Amsterdam, The Netherlands: Elsevier.

Hodson, D. P., Cressman, K., Nazansi, K., Park, R. F., \& Yahahoui, A. (2009). The global cereal monitoring system. In Abstract for the Borlaug global rust initiative technical workshop, 17-20 March, Cindad, Obregon, Mexico. P21. Available at: www.globalrust.org. Last Accessed on April 24, 2009.

Holden, S., Otsuka, K., \& Place, F. (Eds.). (2008). The emergence of land markets in Africa: Impacts on poverty, equity, and efficiency. London: Routledge.

IAASTD (International Assessment of Agricultural Knowledge, Science and Technology for Development). (2009). Agriculture at a crossroads (Sub-Saharan Africa (SSA) Report, Vol. V). International Assessment of Agricultural Knowledge, Science and Technology for Development.

IFAD (International Fund for Agricultural Development). (2003). Agricultural marketing companies as sources of smallholder credit in east and southern Africa: Experiences, insights and potential donor roles. Rome, Italy: IFAD East and Southern Africa Division, IFAD.

IFPRI (International Food Policy Research Institute). (2012). Increasing Agricultural productivity $\&$ enhancing food security in Africa. In Synopsis of an International Conference New Challenges Opportunities. Washington, DC. USA: International Food Policy Research Institute.

Jayne, T. S., \& Jones, S. (1997). Food marketing and pricing policy in Eastern and Southern Africa: A survey. World Development, 25(9), 1505-1527.

Kebede, B. (2002). Land tenure system and common pool resources in rural Ethiopia: A study based o fifteen states. Africa Development Review, 14, 113-150.

Kelly, V., Adesina, A., \& Gordon, A. (2003). Expanding access to agricultural inputs in Africa: A review of recent market development experience. Food Policy 28, 379404.

Langyintuo, A. S. (2004). Challenges of the seed sector of southern Africa (p 39) (International Maize and Wheat Improvement Centre (CIMMYT Report). Harare, Zimbabwe. At www.cimmyt. org/gis/rfseedsafrica/.

Langyintuo, A. S., \& Setimela, P. (2007). Assessment of the effectiveness of maize seed assistance to vulnerable farm households in Zimbabwe. Mexico, D.F.: CIMMYT.

Langyintuo, A. S., Mwangi, W., Diallo, A. O., MacRobert, J., Dixon, J., \& Bänziger, M. (2010). Challenges of the maize seed industry in eastern and southern Africa: A compelling case for private-public intervention to promote growth. Food Policy, 35, 323-331.

Levitsky, J. (1997, February, May). Best practice in credit guarantee schemes. The Financier, Vol. 4 , No. 1 and 2.

Louwaars, N. P., \& Engels, J. M. M. (2008). Seed policies: Enabling support to informal seed systems. Research Gate. Available on http://www.researchgate.net/publications/37789145.

Magingxa, L., \& Kamara, A. (2003). Institutional perspectives of enhancing smallholder market access in South Africa. Paper presented at the 41st Annual Conference of the Agricultural Economic Association of South Africa held in Pretoria. Diao and Hazell 2004.

Morris, M., Ronchi, R., \& Rohrbach, D. (2011). Building sustainable fertilizer markets in Africa. In Proceedings of International Conference on Priority Actions Toward Market Development for African Farmers. Nairobi, Kenya: International Livestock Research Institute. 
Mwala, M., \& Gisselquist, D. (2012). Private-sector agricultural research and innovation in Zambia: Overview, impact, and policy options. Lusaka, Zambia: University of Zambia. Technology Foundation (AATF), Nairobi, Kenya.

Namubiru-Mwaura, E. L., Knox, A., \& Hughes, A. (2012). Customary land tenure in Liberia: Findings and implications drawn from 11 case studies (Report prepared for the Liberia Land Policy \& Institutional Support (LPIS) Project). Washington, DC: United States Agency for International Development.

NEPAD. (2004). Implementing the comprehensive Africa agriculture development programme and restoring food security in Africa. Available at www.nepad.org/2005/files/documents/172.pdf. NEPAD, South Africa.

Olson, J., \& Berry, L. (2003). Land degradation in Uganda: Its extent and impact. Mimeo.

Paarlberg, R. L. (2000). Governing the GM crop revolution policy choices for developing countries (p. 44) (Food, Agriculture, and the Environment Discussion Paper 33). Washington, D. C: International Food Policy Research Institute.

Paarlberg, R. L. (2002). The real threat to GM crops in poor countries: Consumer and policy resistance to GM foods in rich countries. Food Policy, 27, 247-250.

Paarlberg, R. (2008). Starved for science: How biotechnology is being kept out of Africa. Cambridge, MA: Harvard University Press.

Paarlberg, R. L. (2014). Why green revolution food crops went forward, while GMO food crops did not. http://www.fao.org/fileadmin/templates/cfs_high_level_forum/documents/ REPORT_HLEF.pdf 2014.

Place, F. (2009). Land tenure and agricultural productivity in Africa: A comparative analysis of the economics literature and recent policy strategies and reforms. World Development, 37, 13261336.

Poulton, C., Kydd, J., \& Dorward, A. (2006). Overcoming market constraints on pro-poor agricultural growth in sub-Saharan Africa. Development Policy Review, 24(3), 243-277.

Poulton, C., Dorward, A., \& Kydd, J. (1998). The rival of smallholder cash crops in Africa: Public and private roles in the provision of finance. Journal of International Development, 10(1), 85-103.

Resnick, D. (2004). Smallholder African agriculture: Progress and problems in confronting hunger and poverty (DSGD Discussion Paper No. 9). Washington, D.C: International Food Policy Research Institute.

Ruiz Navajas, A. (2001). Credit guarantee schemes: Conceptual frame. Financial system development project, GTZ/FONDESIF, November.

Spielman, D., Ekboir, J., \& Davis, K. (2009). The art and science of innovations systems inquiry: Applications to sub-Saharan African Agriculture. Technology in Society, 31, 399-405.

Swinnen, J. F. M., \& Maertens, M. (2010). Finance through food and commodity value chains in globalized. Paper presented at the KFW Financial Sector Development Symposium Finance for Food: Towards new agriculture and rural finance.

UNECA (Unite Nations Economic Commission for Africa). (2005). Structural transformation to breakaway from poverty. Chap. 4 in Economic report on West Africa. Available at http://www. UNECA.org/eva2005/chap4.pdf. UNECA, Addis Ababa, Ethiopia.

World Bank. (2006). Promoting increased fertilizer use in Africa: Lessons learned and good practice guidelines (Africa Fertilizer Strategy Assessment ESW Technical Report Discussion Draft). Washington, DC. USA.

World Bank. (2008a). The growth report: Strategies for sustained growth and inclusive development. Washington D.C.: Commission on Growth and Development, World Bank.

World Bank. (2008b). The typology of partial credit guarantee funds around the world (Policy Research Working Paper 4771. Development Research Group). Washington DC: The World Bank.

World Bank. (2013). Poverty headcount ratio at national poverty lines (\% of population). Available at: http://data.worldbank.org/indicator/SI.POV.NAHC. Last Accessed on March 2013.

World Bank. (2018). Poverty and shared prosperity 2018: Piecing together the poverty puzzle. Washington, D.C.: The World Bank. 
World Bank. (2019). The World Bank data. Available at: https://data.worldbank.org/indicator/AG. CON.FERT.ZS?view=chart.

Dr. Augustine Langyintuo is a senior agribusiness specialist with the World Bank Group. Based in the Nairobi, Kenya, regional office of the World Bank, he leads agribusiness development in East and Southern Africa with global responsibility for seed sector policy reforms. Prior to joining the World Bank in 2013, Dr. Langyintuo was the head of policy and partnerships of the Alliance for a Green Revolution in Africa (AGRA) from 2009. Before joining AGRA, he was an economist/socio-economics team leader at the International Maize and Wheat Improvement Center (CIMMYT) from 2003. While heading the Socio-Economics Unit of the Savanna Agricultural Research Institute in Ghana between 1994 and 1998, Dr. Langyintuo also lectured on natural resource economics, farm management and accounting, and computing and programming at the University for Development Studies, Ghana. At CIMMYT and AGRA, he supervised post-graduate students in various universities in Africa and North America. An agricultural trade economist and an agribusiness expert, he has over 100 scholarly publications in peer-reviewed journals, conference proceedings and special reports. He currently serves as an associate editor of the African Journal of Agricultural and Resource Economics and reviews for several international Journals. Affiliated to many professional bodies, he is the current President of the African Association of Agricultural Economists and served on the 2015 Nominations Committee of the International Association of Agricultural Economists. A founding member and executive board member of the Foundation for Rural Education, Empowerment and Development, he also serves as a member of the Advisory Board of the Drought Tolerant Maize for Africa project of CIMMYT and the United Nations Development Programme Report on Inclusive Business and their Ecosystems in Africa. Dr. Langyintuo received the 2014 APEX Award from the Department of Agricultural Economics, Purdue University, USA, for excelling in his professional career. He holds a Ph.D. in agricultural economics from Purdue University, a master's degree in agricultural economics from Reading University, United Kingdom, and a bachelor's degree in agriculture from Kwame Nkrumah University of Science and Technology, Kumasi, Ghana.

Open Access This chapter is licensed under the terms of the Creative Commons Attribution 4.0 International License (http://creativecommons.org/licenses/by/4.0/), which permits use, sharing, adaptation, distribution and reproduction in any medium or format, as long as you give appropriate credit to the original author(s) and the source, provide a link to the Creative Commons license and indicate if changes were made.

The images or other third party material in this chapter are included in the chapter's Creative Commons license, unless indicated otherwise in a credit line to the material. If material is not included in the chapter's Creative Commons license and your intended use is not permitted by statutory regulation or exceeds the permitted use, you will need to obtain permission directly from the copyright holder.

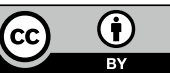

